\title{
Vi troede ikke, det kunne ske her. Jugoslaviens sammenbrud 1991-1999
}

\author{
Christian Axboe Nielsen \\ Kristeligt Dagblads forlag: København 2018 \\ 335 sider. ISBN 9788774672890
}

Omtalt av Dragana Kovačević Bielicki [PhD, Institutt for litteratur, områdestudier og europeiske språk, Universitetet i Oslo, dragana.kovacevic@yahoo.com]

Trenger vi virkelig enda en bok om Jugoslavias sammenbrudd? Det lurte jeg på med en gang jeg leste tittelen på Christian Axboe Nielsens nye bok. Jugoslavias sammenbrudd har nemlig blitt skrevet om nesten utallige ganger, av en rekke forskjellige forfattere. Det kan virke som om det ikke lenger kan være noe nytt eller nyttig å fortelle om dette sammensatte temaet. Tidlig i boken ble det imidlertid klart at forfatteren selv stiller dette spørsmålet eksplisitt, og at han tar det på alvor. Etter å ha lest boken, er jeg overbevist om at den er et viktig bidrag til den vitenskapelige diskusjonen om krigene i Jugoslavia, uavhengig av litteraturen som allerede har blitt publisert om temaet.

Axboe Nielsen demonstrerer at han kan belyse sammenbruddet ut fra nye vinkler, gjennom akademisk forskning og ikke minst gjentatte erfaringer som vitneekspert for The International Criminal Tribunal for the former Yugoslavia (ICTY). Han bruker nemlig kunnskap om enkeltsaker til å supplere et ovenfra-ned historisk perspektiv med en nedenfra-opp-tilnærming. I tillegg viser forfatteren hvordan erfaringer fra Jugoslavia kan brukes til å advare mot nasjonalismens og populismens farer, som er vel så aktuelle i dag som tidligere. Axboe Nielsens refleksive jeg-stemme og meninger om betydningen av kontinuerlig kritisk revurdering av Jugoslavias oppløsning kommer klarest til syne mot slutten av boken, særlig i etterordet. På grunn av hans erfaringer fra ICTY er det veldig viktig at denne stemmen er med, og ikke minst at den vises som ekte, ærlig og menneskelig.

Ikke overraskende for en historiker velger forfatteren en stort sett kronologisk tilnærming og klarer å bruke denne effektivt. Han går også frem og tilbake i tid for å trekke konklusjoner eller sammenligne hendelser når dette er nødvendig. Den kronologiske rekkefølgen er av og til vanskelig å holde seg til når man også må beskrive forskjellige geografiske områder og parallelle prosesser. Her viser Axboe Nielsen sin faglige styrke og klarer å navigere gjennom den komplekse historien på en vidunderlig klar måte. Til tross for at forfatteren spesifiserer perioden 1991-1999 i bokens 
tittel, visste han nok godt at han måtte ta for seg historien både før og etter denne perioden. Det var særlig gledelig å oppdage at han mot slutten av boken reflekterer over nåtidens situasjon $\mathrm{i}$ alle de tidligere republikkene. Refleksjonene er korte, men slett ikke overfladiske eller uviktige.

Axboe Nielsens oversikt har ingen vesentlige mangler. Fakta er presentert på en systematisk måte, mens stil og språk giør boken lett å lese og følge. Det kan godt nevnes her at boken også er vanskelig å lese, følelsesmessig. Den inneholder mange detaljerte opplysninger om brutale måter mennesker ble behandlet på. Forfatteren advarer om dette voldsomme innholdet på forhånd. Samtidig er det et viktig og forstålig intellektuelt og menneskelig valg han har gjort. På denne måten kommer enkeltmenneskene og særlig ofrene til orde. Jeg mener dette perspektivet er nødvendig, og jeg skulle ønske at forfatteren hadde latt disse historiene komme frem enda oftere og enda mer omfattende. Selv om konkrete forbrytelser er vanskelige temaer å ta opp, vil forfatterens innsats med å konkretisere dem hjelpe leserne til å forstå, og til å huske hendelsene og lære av dem. Det er lett å forstå at Axboe Nielsens kjennskap til detaljer for det meste kommer fra de rettsakene han var involvert $i$. Det ville imidlertid vært nyttig for leseren om forfatteren hadde klart å inkludere opplysninger om konkrete overtredelser og ofre i flere saker. Særlig når det gjelder militæraksjonen «Storm» i Kroatia, mangler boken konkrete eksempler på hvordan enkeltmennesker led, selv om forfatteren hevder på generelt grunnlag at aksjonen medførte mange forbrytelser som til den dag i dag forblir ustraffet. Et annet eksempel på fravær av viktige detaljer er at forfatteren nevner at det fantes konsentrasjonsleirer også i Kosovo, men unnlater å gi konkrete opplysninger om dem. Disse leirene er sjeldent nevnt eller skrevet om, sammenlignet med de bosniske leirene. Derfor mister vi også her en mulighet til å lære mer om dette temaet.

Fordi boken inneholder en stor mengde detaljer, blir stilen som oftest rent deskriptiv. Forfatteren er imidlertid særlig overbevisende når han inkluderer egen analyse og innsikt. Han viser for eksempel hvor viktig det er å utfordre den utbredte tendensen til å benekte eller relativisere forbrytelser begått av «egen side». I tillegg viser forfatteren en stor evne til å være rettferdig og balansert. Alle og alles beskrivelser av hendelsene i Jugoslavia kan lett bli møtt med anklager om partiskhet, men etter min mening fortjener ikke Axboe Nielsen slike beskyldninger.

Forfatteren er altså en historiker, en utmerket sådan, som her blir lest og kommentert fra et samfunnsvitenskapelig konstruktivistisk perspektiv. Sett fra en slik vinkel er nesten all (og ikke bare) historieskriving i fare for å generalisere og forenkle komplekse prosesser og vil kunne bli beskyldt for å forestille konstruerte grupper som reelle aktører. Dette kan føre til en illusjon av objektivitet og mangel på selvreflekterende kritikk innenfor historieskriving. Axboe Nielsens perspektiv er et klart unntak fra dette. Han reflekterer tydelig over farene akademikere står overfor når det gjelder å forsterke nasjonalisme og ekskludering ved å bruke ureflekterte etiketter og ukritiske generaliseringer. Forfatteren bruker både etnografisk innsikt og kunnskap om kilder, og trekker på debatter som stammer fra sosiologi og sosialantropologi. 
Her vil jeg særlig berømme hans sterke kritiske utfordring av balkanisme og eurosentrisme. Han tar ingen ideologier for gitt, men det er som kjent uansett vanskelig å gjennomgående unngå å bruke problematiske konsepter. Jeg var særlig sensitiv på en gjentakende bruk av uttrykket "sett med X øyne», hvor det i stedet for X for eksempel står «amerikanske», «danske», «hærens», «serbiske» og så videre. Dette utrykket kan virke veldig sterkt og generaliserende.

Axboe Nielsen bruker som regel godt verifiserte fakta og referanser, men av og til velger han også å gi plass til spekulative påstander, til og med konspirasjonsteorier. Han fremstiller ikke disse som fakta, men bruker dem fordi de er en stor del av dominerende diskurser og tolkninger i regionen. Det ville vært en styrke om forfatteren var tydeligere på hva disse spekulasjonene og teoriene er, og hvor de muligens stammer fra. Dette er ikke alltid tilfelle i boken, og noen lesere vil da ikke kunne gjenkjenne og skille spekulasjoner fra fakta. Dessuten skulle jeg ønske at forfatteren passet på å alltid bruke klare kilder for statistikken han nevner, særlig når det gjelder folketall. I gjentatte tilfeller nevner han prosentandel av forskjellige etnisiteter og andre grupper uten å vise til kilder.

Avslutningsvis vil jeg nevne at jeg skulle ønske jeg selv hadde denne boken tilgjengelig da jeg tidligere underviste i Jugoslavias samfunn og historie på Universitetet i Oslo. Jeg vil uten tvil anbefale å inkludere denne boken i pensum. Den ville giøre det mulig for studenter og forskere å få en omfattende, men samtidig forståelig introduksjon til et komplekst og omstridt studiefelt, uavhengig av deres forkunnskap. 